al. Relevance of digestive tract colonization in the epidemiology of nosocomial infections due to multiresistant Acinetobacter baumannii. Clin Infect Dis 1996;23:329-333.

13. Timsit JF, Garrait V, Misset B, Goldstein FW, Renaud B, Carlet J. The digestive tract is a major site for Acinetobacter baumannii colonization in intensive care unit patients. J Infect Dis 1993;168:1336-1337.

14. Hartstein AJ, Rashad AI, Liebler JM, Actis LA, Freeman J, Rourke JW, et al. Multiple intensive care unit outbreak of Acinetobacter calcoaceticus subspecies anitratus respiratory infection and colonization associated with contaminated reusable ventilator circuits and resuscitation bags. Am J Med 1988;85:624-631.

15. Gervich DH, Grout CS. An outbreak of nosocomial Acinetobacter infections from humidifiers. Am I Infect Control 1985;13:210-215.

16. Villers D, Espaze E, Coste-Burel M, Giauffret F, Ninin E, Nicolas F, et al. Nosocomial Acinetobacter baumannii infections: microbiological and clinical epidemiology. Ann Intern Med 1998;129:182-189.

17. Gouby A, Carles-Nurrit MJ, Bouzigues N, Bourg G, Mesnard R, Bouvet PJ. Use of pulsed-field gel electrophoresis for investigation of hospital outbreaks of Acinetobacter baumannii. J Clin Microbiol 1992;30:1588-1591.

18. Garner JS, Jarvis WR, Emory TG, Horan TC, Hughes JM. CDC definitions for nosocomial infections. Am J Infect Control 1988;16:128-140.

19. Chastre J, Fagon JY, Soler P, Bornet M, Domart Y, Trouillet JL et al. Diagnosis of nosocomial bacterial pneumoniae in intubated patients undergoing ventilation: comparison of the usefulness of bronchoalveolar lavage and the protected specimen brush. Am J Med 1988;85:499-506.

20. Brun-Buisson C, Abrouk F, Legrand P, Huet Y, Larabi S, Rapin M. Diagnosis of central venous catheter-related sepsis: critical level of quantitative tip cultures. Arch Intern Med 1987;47:873-877.

21. Pickett MJ, Hollis DG, Bottone EJ. Miscellaneous gram-negative bacteria. In: Balows A, Hausler WJ, Herrmann KL, Isenberg HD, Shadomy HJ, eds. Manual of Clinical Microbiology. 5th ed. Washington, DC: American Society for Microbiology; 1991:410-428.

22. Garner JS, the Hospital Infection Control Practices Advisory Committee. Guideline for isolation precautions in hospitals. Infect Control Hosp Epidemiol 1996;17:53-80.

23. Hospital Infection Control Advisory Committee. Recommendations for preventing the spread of vancomycin resistance. Infect Control Hosp Epidemiol 1995;16:105-113.

24. McCabe WR, Jackson GG. Gram negative bacteremia: etiology and ecology. Arch Intern Med 1962;110:847-852.

25. Knaus WA, Draper EA, Wagner DP, Zimmerman JE. Prognosis in acute organ-system failure. Ann Surg 1985;11:685-693.

26. Knaus WA, Draper EA, Wagner DP, Zimmerman JE. APACHE II: a severity of disease classification system. Crit Care Med 1985;13:818-829.

27. Keene AR, Cullen DJ. Therapeutic Intervention Scoring System. Crit Care Med 1983;11:1-3.

28. Tankovic J, Legrand P, De Gatines $G$, Chemineau V, Brun-Buisson C, Duval J. Characterization of a hospital outbreak of imipenem resistant Acinetobacter baumannii by phenotypic and genotypic methods. $J$ Clin Microbiol 1994;32:2677-2681.
29. Dijkshoorn L, Aucken H, Gerner-Smidt P, Janssen P, Kaufmann ME, Garaizar J, et al. Comparison of outbreak and non-outbreak Acinetobacter baumannii strains by genotypic and phenotypic methods. J Clin Microbiol 1996;34:1519-1525.

30. Lyytikäinen O, Köljalg S, Härmä M, Vuopio-Varkila J. Outbreak caused by two multiresistant Acinetobacter baumannii clones in a burns unit: emergence of resistance to imipenem. J Hosp Infect 1995;31: 41-54.

31. Levin ASS, Mendes CMF, Sinto SI, Sader HS, Scarpitta CRM, Rodrigues $\mathrm{E}$, et al. An outbreak of multiresistant Acinetobacter baumannii in a university hospital in Sao Paulo, Brazil. Infect Control Hosp Epidemiol 1996;17:366-368.

32. Rosenthal SL. Sources of Pseudomonas and Acinetobacter species found in human culture materials. Am J Clin Pathol 1974;62:807-811.

33. Beck-Sagué CM, Jarvis WR, Brook JH, Culver DH, Potts A, Gay E, et al. Epidemic bacteremia due to Acinetobacter baumannii in five intensive care units. Am J Epidemiol 1990;132:723-733.

34. Joly-Guillou ML, Brun-Buisson C. Epidemiology of Acinetobacter. surveillance and management of outbreaks. In: Bergogne-Berezin $\mathrm{E}$, JolyGuillou ML, Towner KJ, eds. Acinetobacter, Microbiology, Epidemiology, Infections and Management. London, UK: CRC Press; 1996:71-100.

35. Arnow PM, Allyn PA, Nichols EM, Hill DL, Pezzlo M, Bartlett RH Control of methicillin-resistant Staphylococcus aureus in a burn unit: role of nurse staffing. J Trauma 1982;22:954958.

36. Fridkin SK, Pear SM, Williamson TH, Galgiani JN, Jarvis WR. The role of understaffing in central venous catheter-associated bloodstream infection. Infect Control Hosp Epidemiol 1996;17:150-158.

37. Jarvis WR, Edwards JR, Culver DH, Hughes JM, Horan T, Emori TG, et al. Nosocomial infection rates in adult and pediatric intensive care units in the United States. Am J Med 1991;91(suppl 3B):S185-S192.

38. Bonten NJM, Slaughter S, Ambergen AW, Hayden MK, Van Voorhis J, Nathan $C$, et al. The role of colonization pressure in the spread of vancomycin-resistant enterococci: an important infection control variable. Arch Intern Med 1998;158:1127-1132.

39. Knaus WA, Legall JR, Wagner DP, Loirat P, Cullen DJ, Glaser P, et al. A com parison of intensive care in the USA and France. Lancet 1982;2:642-646.

40. Cullen DJ, Civetta JM, Briggs BA, Ferrara LC. Therapeutic Intervention Scoring System: a method for quantitative comparison of patient care. Crit Care Med 1974;2:57-60.

41. Miranda RD, Moreno R, Iapichino G. Nine equivalents of nursing manpower use score. Intens Care Med 1997;23:760-765.

42. Mälstam J, Lindt L. Therapeutic Intervention Scoring System (TISS)-a method for measuring workload and calculating costs in the ICU. Acto Anaesthesiol Scand 1992;36:758-763.

43. Haley RW, Cushion NB, Tenover FC, Bannerman TL, Dryer D, Ross J, et al. Eradication of endemic methicillin-resistant Staphylococcus aureus infections from a neonatal intensive care unit. I Infect Dis 1995;171:614-624.

44. Girou E, Stephan F, Novara A, Safar M, Fagon JY. Risk factors and out come of nosocomial infections: results of a matched case-control study of ICU patients. Am J Respir Crit Care Med 1998;157:1151-1158.

\title{
Management of CVCs in Patients With Candidemia
}

\section{Gina Pugliese, RN, MS Martin S. Favero, PhD}

Controversy exists regarding the most appropriate acute management of central venous catheters (CVCs) in neonates with candidemia, with up to two thirds of neonatologists preferring to attempt antifungal therapy without removing CVCs. Karlowicz and coinvestigators from Eastern Virginia Medical School, Children's Hospital of The King's Daughters, Norfolk, Virginia, conducted a study to determine whether CVCs should be removed as soon as candidemia is detected in neonates. A cohort study of candidemia and CVCs was conducted in infants in a neonatal ICU over a 5 -year period (1994-1998).

Fifty infants had early removal (ER) of a CVC (within 3 days), and 54 infants had late removal (LR) of a CVC ( $>3$ days after the first blood culture positive for Candida species). All infants were treated with amphotericin B. There was no significant difference between infants in the ER CVC and LR CVC groups in terms of gender, ethnicity, birth weight, gestational age, age at candidemia, severity-of-illness scores, distribution of types of CVC, or in the distribution of Candida species causing candidemia. The ER CVC group had significantly shorter duration of candidemia (median, 3 days; range, 1-14 days) compared with the LR CVC group (median, 6 days; range, 1-24 days). The case fatality rate of Candida albicans candidemia was significantly affected by the timing of CVC removal: 0 of 21 (95\% confidence interval $\left.\left[\mathrm{CL}_{95}\right], 0-14\right)$ infants died in the ER CVC group in contrast to 9 of $23\left(39 \%\right.$; $\mathrm{CI}_{95}, 19$ $59)$ in the LR CVC group. The authors concluded that failure to remove a CVC as soon as candidemia was detected in neonates was associated with significantly increased mortality in $C$ albicans candidemia and prolonged duration of candidemia regardless of Candida species.

FROM: Karlowicz MG, Hashimoto LN, Kelly RE Jr, Buescher ES. Should central venous catheters be removed as soon as candidemia is detected in neonates? Pediatrics 2000;106:E63. 